\title{
The Strategy Research of Education Management based on Cultivating Innovative Talents in University
}

\author{
Baohua Cui \\ Economic Management Department, \\ Jilin Agricultural University, \\ Changchun, China \\ Email: cbhjlau@yeah.net
}

Key words: creative talents; teaching management; strategy

\begin{abstract}
It is the fundamental work for universities and colleges to cultivate creative talents, to which teaching is the main way. Teaching management is the core of college administration. Faced with the new situation of national educational reforms, universities and colleges should base themselves on innovation and personnel training and explore a new model of teaching management for the growth of creative talents by updating ideas, optimizing mechanism, creating carriers, etc.
\end{abstract}

\section{Introduction}

Innovation is the soul of national progress, is the inexhaustible power of national prosperity.Cultivation of innovative talents plays an important role in the socio-economic development and progress, also are the basis of knowledge innovation and technological innovation, while in the training process of innovative talent, we inevitably involves management problems, which is the core of the teaching management. In today's society, knowledge is constantly increasing so that we must constantly updated teaching programs, content and curriculum, which requires that we must constantly change teaching management to ensure effective implementation of teaching objective. For administrators, they directly service and participate in implement of teaching activities, how to construct the teaching management system supporting the cultivation of innovative talents in universities, has become an important topic worthy of further consideration and exploration.

\section{The relationship between cultivation of innovative talents and teaching management in universities}

A. The innovation of teaching management is the prerequisite for cultivating innovative talents.

The growth of innovative talents needs conditions, one of the most important condition must innovative teaching management. Innovative education focuses on the personality development of the students, demands to implement "people-oriented" idea in teaching management, create actively an environment which are benefit for students' learning independently, encourages students to discovery question, ask questions and discuss questions equally and freely, provide favorable conditions for outstanding students ${ }^{[1]}$.

\section{B. The training of innovative talents promotes the innovation of teaching management}

The 21st century is an innovative society, "innovative education and social development of both the external requirements for university education, but also the inherent need to improve their competitiveness in the university" to train high quality innovative talents increasingly become a university education is the most important work. In such a context, the imminent developments, the needs of colleges and universities teaching management will lag behind if the rigid development of higher education, become an obstacle to personnel training. In this sense, the innovative talents in 
promoting the teaching management innovation, promote the teaching management to meet the needs of innovative education.

\section{The level of teaching management affects effectiveness of training innovative talents}

Innovative Talent and Teaching Management in a sense, reinforce each other, influence each other. Innovative education requires educational administrators have a new concept of education and a wide range of knowledge and ability, but also requires educational administrators dialectical relationship between strict and lenient treatment, principles and flexible, inheritance and innovation in management practice, to do this itself reflecting the level of teaching management ${ }^{[2]}$. A university, a high level of teaching management, innovative educational results will certainly be better. On the contrary, teaching management confusion, it will certainly affect the smooth conduct innovative education.

\section{Teaching management factors that restricts the cultivation of innovative talents}

The cultivation of innovative talents and teaching management are complementary to each other, but in the actual process of teaching management, the traditional management model hampers cultivation of top-notch creative talents, mainly in the following areas:

\section{A. The administration of teaching management}

The teaching management in university are actually an extension of government management. The teaching administrators as leaders, dominate teaching operation. Teachers and students are lack of innovative opportunities in which they can actively join and manage.

\section{B. The modeling of teaching concept}

The management concept of many educational administrators are old-fashioned and lack of creativity, copy invariably management system, mechanically perform administrative commands. The teaching management stays in the level of conventional management, greatly hinders the cultivation of top innovative talents.

\section{The simplification of management content}

Today, the teaching process is no longer limited to the classroom, scientific innovative activities out of class and practical activities out of school are important parts. "second class" and "third class" stimulate the students' self-learning ability and innovative practical ability. But majority of teaching administrators still follow the traditional contents and ways of teaching management, are limited to monitoring of classroom teaching ${ }^{[3]}$. Teachers' performance in the teaching process and evaluation for teaching results, cause fraction in cultivation of innovative ability and deletion of management content.

\section{One-side content of teaching evaluation}

Currently, the evaluation ways in majority universities are final exam assessment, but this method only focus on final scores, ignore students' performance everyday, can't truly assess students' learning. This kind of assessment method only can reflect students' preparation degree for examination, can't reflect the students' real ability, and easily leads to rote learning for students, can't stimulate students' creative thinking, seriously restricts cultivation of students' innovative ability.

\section{The strategy of teaching management based on innovative talents cultivation}

A. Transfer the concept of education management, enhance the quality of administrators

Cultivation of innovative talents, we first need to change educational concept for teachers and administrators, keep up with the trend of the era. We not only put our attention to teaching knowledge, but also the cultivation of practical and innovative ability. Teaching managers need to improve their literacy by changing their ideas. First of all, administrators in universities should 
stress "people-oriented", establish talent concept, knowledge concept, education concept and quality concept which are suitable for ages, take coordinating development including knowledge, ability and quality as an important basis to measure quality of talents, combine closely cultivation of innovative talents with social development and progress ${ }^{[4]}$. Secondly, teaching administrators should change the traditional administrative thinking, establish administrative new concept with democracy and harmony, improve constantly the ways and means of service, establish the administrative image serving for teaching, establish harmonious work relationship. Thirdly, educational administrators in teaching management seek a unified combination between rigid system and flexible management; in teaching management process, we should pay attention to spiritual inspiration and emotional investment. Finally, in design concept of administrative system, we not only pay attention to forming healthy competition between teachers and students, but promote cooperative awareness between various teaching units. Only we change fully teaching management concepts, enhance our quality, can we lay a good foundation for improving the overall innovative capability and education effectiveness.

\section{B. Construct a scientific and reasonable curriculum system}

Scientific research of undergraduate as part of the teaching, should be included in undergraduate training program,as long as undergraduate complete successfully research task, they can get research credits. Such reforms can make undergraduates contact real scientific research as early as possible, are the best way to cultivate capacity, has immeasurable benefits for their innovation and creativity in future workplace.

- Optimize curriculum structure of undergraduate. By means of setting curriculum scientifically, we value students' achievement effectively, guide students to have a comprehensive learning and development in order to build research learning course system of university. Firstly, new curriculum modules, we stand out research of setting curriculum from course objectives, course implementation to course format, focus on the word "research". Secondly, professional curriculum modules. we focus on personality development of students, have targeted setting, cultivate students' habits of research study, teach students research methods, train research capacity to improve research awareness and research quality for students. Finally, research topic module, we set up research topic in order to guide directions for learners, set curriculum comprehensively around one topic, make students apply their knowledge, concert knowledge to ability as soon as possible.

Open innovative theory and skills courses. The cultivation of innovative talents can't do without the support from innovation theory and skills, both of which constitute an important part and an essential element for students' innovation ability. We set up a certain amount of innovation theory and skills courses so that students enrich scientific knowledge, improve practical ability through learning and training of innovative skills, cultivate quality of innovative thinking, strengthen the depth of innovative thinking. Students will greatly enhance the efficiency of invention and innovation after learning and training ${ }^{[5]}$.

\section{Refinement of teaching quality management monitoring}

The achievement assessment from students courses is an important part of the teaching process. Teaching management based on cultivation of innovative talents should actively implement developed and whole evaluation thinking, change the only evaluate way which take qualifications and scores as absolute standards, we will bring new quality standards into teaching management monitoring and evaluation of teaching quality, such as classroom teaching, experience teaching, practical teaching, thesis and curriculum examination. We establish teaching quality and students' evaluation system which involves knowledge information, skills, thinking quality and creativity. In the examination form, we use a comprehensive approach of written, oral and skills assessment, focus on testing students' ability to apply knowledge and solve problems, encourage students raise multifarious and unique answers. Achievement assessment of course examinations separate teat from teaching, combine quizzes, classroom discussions with final examination, gradually increase the proportion of average grades. We are strict to examination management and promote building 
work of test bank. We introduce incentive and competitive mechanism, gradually introduce the system that teachers teach competitively and students elect independently, take the quality of teaching as an important basis for appointment of teachers. At the same time, we should establish systems such as listening to lectures, value lectures and test analysis that adapts to teaching quality supervision, so that we make an accurate evaluation of classroom teaching, lay a solid foundation for cultivation of innovative talents in university.

\section{Conclusion}

In summary, teaching management is very important factor of top innovative talents, and cultivate innovative talents of university teaching management has put forward new demands, the two complement each other. We should effectively provide a new opportunity and a platform for innovation and personnel training, improve the quality of personnel training of colleges.

\section{References}

[1] Gao Hai, Shen Tian. Research of Characteristics of Top-notch innovative personnel train ing mode, [J]. Teaching and Research, 2012, (1).

[2] Wang Shengshui. On the training of the Innovation Talents from the view of Characteri stics of American Higher Education, [J]. journal of Higher Education Management, 2012, 6 (2).

[3] Cui Jian. On Reform and innovation of university Teaching Management mode in new era, [J]. The Guide of Science \& Education, 2010, (2).

[4] Zhu Hui. On Countermeasures of Higher Education Management Innovation-------- From the perspective of Innovative Talents, [D]. Nanjing: Humanities and Social Sciences Co llege, Nanjing University of Aeronautics and Astronautics, 2008, (3): 7.

[5] Leng Shuang. On teaching management innovation based on the target of cultivating in novative talents, [J]. Heilongjiang Education, 2009 (1). 